\title{
Effect of Different Dietary Protein Levels on Growth and Proximate Composition of the Eggs and Broodstock of Giant Murrel, Channa marulius (Forsskal)
}

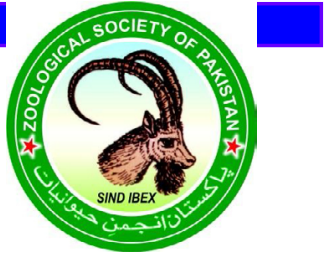

\author{
Muhammad Hafeez-ur-Rehman', Farzana Abbas' ${ }^{2}$, Ghulam Abbas ${ }^{3, *}$, Arshad Javid ${ }^{4}$, \\ Ali Hussain ${ }^{4}$, Syedah Andleeb ${ }^{5}$, Khalid Javed Iqbal ${ }^{6}$ and Muhammad Akmal ${ }^{1}$
}

${ }^{1}$ Department of Fisheries and Aquaculture, University of Veterinary and Animal Sciences, Lahore, Pakistan

${ }^{2}$ Department of Zoology, University of Okara, Okara, Pakistan

${ }^{3}$ Center of Excellence in Marine Biology, University of Karachi, Karachi, Pakistan ${ }^{4}$ Department of Wildlife and Ecology, University of Veterinary and Animal Scienca Lahore, Pakistan

${ }^{5}$ Department of Zoology, Govt. Postgraduate Islamia College for Wome Road, Lahore, Pakistan ${ }^{6}$ Department of Life Sciences, The Islamia University of Bahawa $>$ akistan $<$ Received 05 September 2017
Available online 11 March 2018
Authors' Contribution
MHR conceived and designed the
study and wrote the manuscript. FA
managed the brooders. GA formulated
the feed and AR did chemical
analysis. AH, SA and MA edited the
manuscript. KJI analysed the data.
Key words
Body composition, Variable protein,
Broodfish, Body growth, Channa
marulius. A B S T R A C T

This research was performed to study the effect of different dietal bro levels on the growth and chemical conformation of broodfish and its eggs. There were three $T_{1}, T_{2}$ and $T_{3}$ ) and a control with three replicates in each group. Control gr $m$ xclusi fed on natural food composed of tilapia fry while fish in $\mathrm{T}_{1}$ was fed on $30 \%, \mathrm{~T}_{2}$ on 0 and on $40 \%$ tein diet, respectively. A total of 240 Channa marulius $(945 \mathrm{~g})$ were arbitrar ${ }^{2} \mathrm{y}$ sto 1 then ponds $(90 \mathrm{ft} \times 70 \mathrm{ft} \times 4 \mathrm{ft}) @ 20$ fish per pond. Fish were fed at $5 \%$ of their body wo two thes per day. The net weight gained of broodstock was $103.65 \mathrm{~g}, 401.25 \mathrm{~g}, 48$ d 565.24 control, $\mathrm{T}_{1}, \mathrm{~T}_{2}$, and $\mathrm{T}_{3}$, respectively. Fish in $\mathrm{T}_{3}$ yielded the highest weight, which was signt ntly higher han $\mathrm{T}_{1}, \mathrm{~T}_{2}$ and control. Specific growth rates were not significant among tre nts. Egg con, ition showed slight and statistically non-discernable variations. Same trend was arved hen brood ck was subjected to analytical tests. Though there was slight increase in lipid an composition but statistically remained non-significant. Our studies suggest that C. mar did ro nd to protein levels in growth and egg quality though with marginal improy ints.

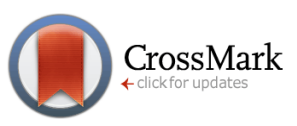

\section{VTRODUCTION}

$\mathrm{F}$ ish nutrition plays a pivotal role in the maintenance of brood stock quality and post-spawning performance which consequently affects breeding and rearing phenomena in fish ponds. Proper maintenance of brood stock is comparatively an expensive preposition, except few fish species, and is normally ignored (Brooks et al., 1997; Izquierdo et al., 2001). Fish hatcheries and commercial fish producers mainly depend on wild brood stock and/or their seed for stopgap arrangements, which is challenging for expansion of fish culture and mass seed production. However, some fish producers accepted such

\footnotetext{
Corresponding author: ghulamabbas@uok.edu.pk 0030-9923/2018/0002-0595 \$ 9.00/0

Copyright 2018 Zoological Society of Pakistan
}

challenges and attempted to explore the role of protein, lipids, minerals, vitamins and ration size of different feeds to enhance reproductive potential and health of brood stock in certain fish species like sea bream, sea bass, common carp, rainbow trout, salmon and tilapia (Mourente and Odriozola 1990; Washburn et al., 1990; Watanabe and Kiron, 1995; Fernandez-Palacios et al., 1995, 1997; Zakeri et al., 2009; Cerda et al., 1994; Manissery et al., 2001; Choubert and Blanc, 1993; Blom and Dabrowski, 1995; Choubert et al., 1998; Pereira et al., 1998; Hardy et al., 1984; Eskelinen, 1989; Berglund, 1995; Christiansen and Torrissen, 1997; de Silva and Anderson, 1995; Cumaratunga and Mallika, 1991; Santiago and Reyes, 1993; Gunasekera et al., 1995, 1996a, b, 1997; Siddiqui et al., 1998).

Protein and lipid are considered as chief constituents of egg yolk which play a significant role in biosynthetic activities during early life stages of embryogenesis in 
specific, and post embryonic stages in general (Metcoff, 1986). Unlike aforementioned fish species, brood stock nutrition of snakeheads, in particular Channa marulius has not been given much attention it deserves. It is very hardy and can be successfully cultured in the areas which totally unfit for agriculture or for culture of other fish species. It exhibits reasonable growth rate and it is popular for its excellent flesh quality and also for its high consumption rate. Although, it is a carnivorous fish, its aquaculture strongly demands well balanced diet as continuous provision of live food will be impractical and uneconomical. Some researchers have devoted their efforts to this important issue but their investigative work was limited to $C$. striata and C. punctata (Hanifa and Sridhar, 2002; Marimuthu and Haniffa, 2007; Hafeez-ur-Rehman et al., 2017). Nothing has so far been documented about development of feeding strategies including spawning of the murrels broodstock in Pakistan. Therefore, this research was planned to examine the effects of different levels of dietary protein on growth performance, biochemical composition of broodstock $(C$. marulius) and level of incorporation in these nutrients of eggs for proper development. Main objective of this study was to know its nutrient requirements both in somatic and reproductive tissue.

\section{MATERIALS AND METHODS? \\ Study site and duration \\ The experiment was conducted in earthen ponds (90 $\mathrm{ft} \times 70 \mathrm{ft} \times 4 \mathrm{ft}$ each) located in Fisheries and Aquaculture Department at Ravi Campus, University of Veterinary and Animal Sciences, Lahore-Pakistan the trial was conducted for one year from June 2011 to May 2012. Experimental set up was arranged by following statistically Complete Randomized Design (Kothari, 2004). In this design, three dietary treatments with a control were studied. Each group including control had three replicates with 20 fish in each. The initial average body weight of C. marulius brood stock was $945.20 \pm 3.30 \mathrm{~g}, 952.83 \pm 2.884 \mathrm{~g}, 943.35 \pm 2.672 \mathrm{~g}$ and $947.88 \pm 2.551 \mathrm{~g}$, in control, $\mathrm{T}_{1}, \mathrm{~T}_{2}$ and $\mathrm{T}_{3}$, respectively. Fishes in control group totally received natural food in the form of alive juvenile tilapia (78\% water contents) at the rate of $40 \%$ of wet body weight of C. marulius broodstock while treatments $\mathrm{T}_{1}, \mathrm{~T}_{2}$, and $\mathrm{T}_{3}$ received $30 \%, 35 \%$ and $40 \%$ protein diet, respectively.}

\section{Experimental diet}

Each diet was formulated independently from well ground fish meal, soybean meal, maize gluten meal, rice polish, molasses, vitamin and mineral premixesin fixed and definite proportions to attain the desired protein level in each experimental group (Table I). Dry formulation was moistened, well kneaded, dried, then crumbled and sifted through $4 \mathrm{~mm}$ sieve to proportionate the particle size to fish mouth gape $(3.5-4.0 \mathrm{~mm})$. The feed was dispensed manually in each pond at $5 \%$ of the wet fish biomass twice a day at 09:00 and 16:30 hours (Javed and Sial, 1991).

Table I.- Ingredient composition of formulated feeds.

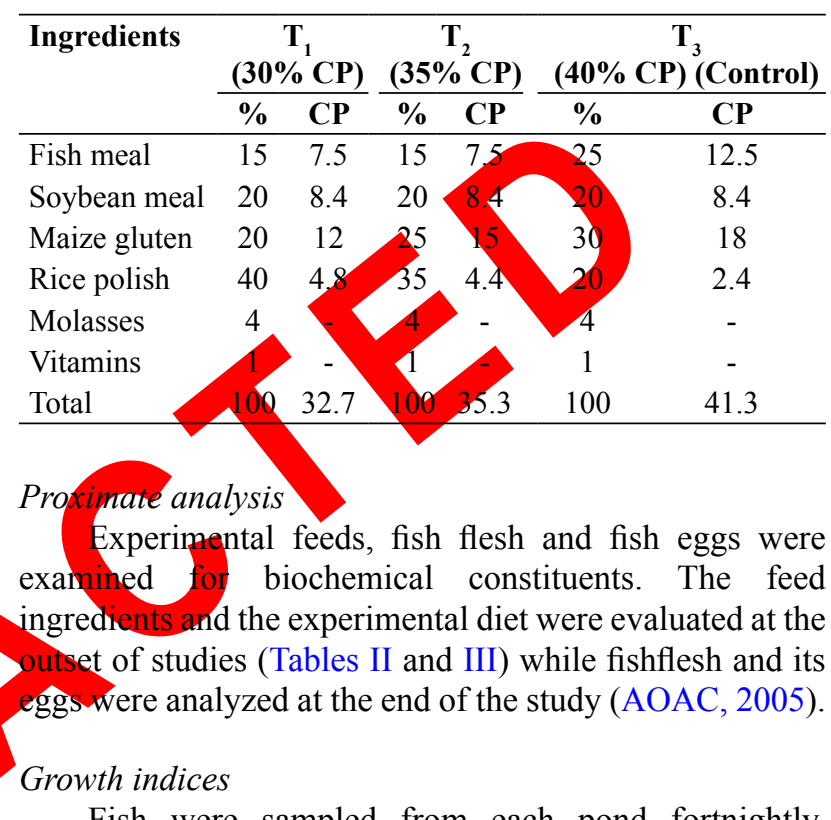

Fish were sampled from each pond fortnightly. Ten fish were arbitrarily chosen from each attempt. The sampled fish were weighed, measured, and then released back into the respective pond. In order to assess meat quality, samples of fish flesh ware taken from each replicate pond for chemical analysis. Growth performance and nutrient utilization were calculated according to the following formulae:

$$
\begin{gathered}
\text { Net weight gain }= \\
\text { final average weight }(\mathrm{g}) \text { - initial average weight }(\mathrm{g}) \\
\text { Percent gain in weight }= \\
\text { net weight gain/initial weight } \times 100
\end{gathered}
$$

Specific growth rate (SGR) was determined by the formula given by Hopkins (1992).

SGR $(\%)=\ln ($ final wet body weight $)-\ln$ (initial wet body weight) $\mathrm{x} 100 /$ number of days

\section{Water quality}

Water quality of the experimental ponds was determined by physical and chemical variables recorded fortnightly at 9.0 to 10.0 A.M. Physical and chemical parameters of pond water were determined by using YSI multi parameter analysis device and salinity was recorded by conductivity meter (Condi 330i WTW 82362 Weilheim, Germany). 
Table II.- Chemical composition of feed constituents (\% dry weight basis) used for Channa marulius brooder diet.

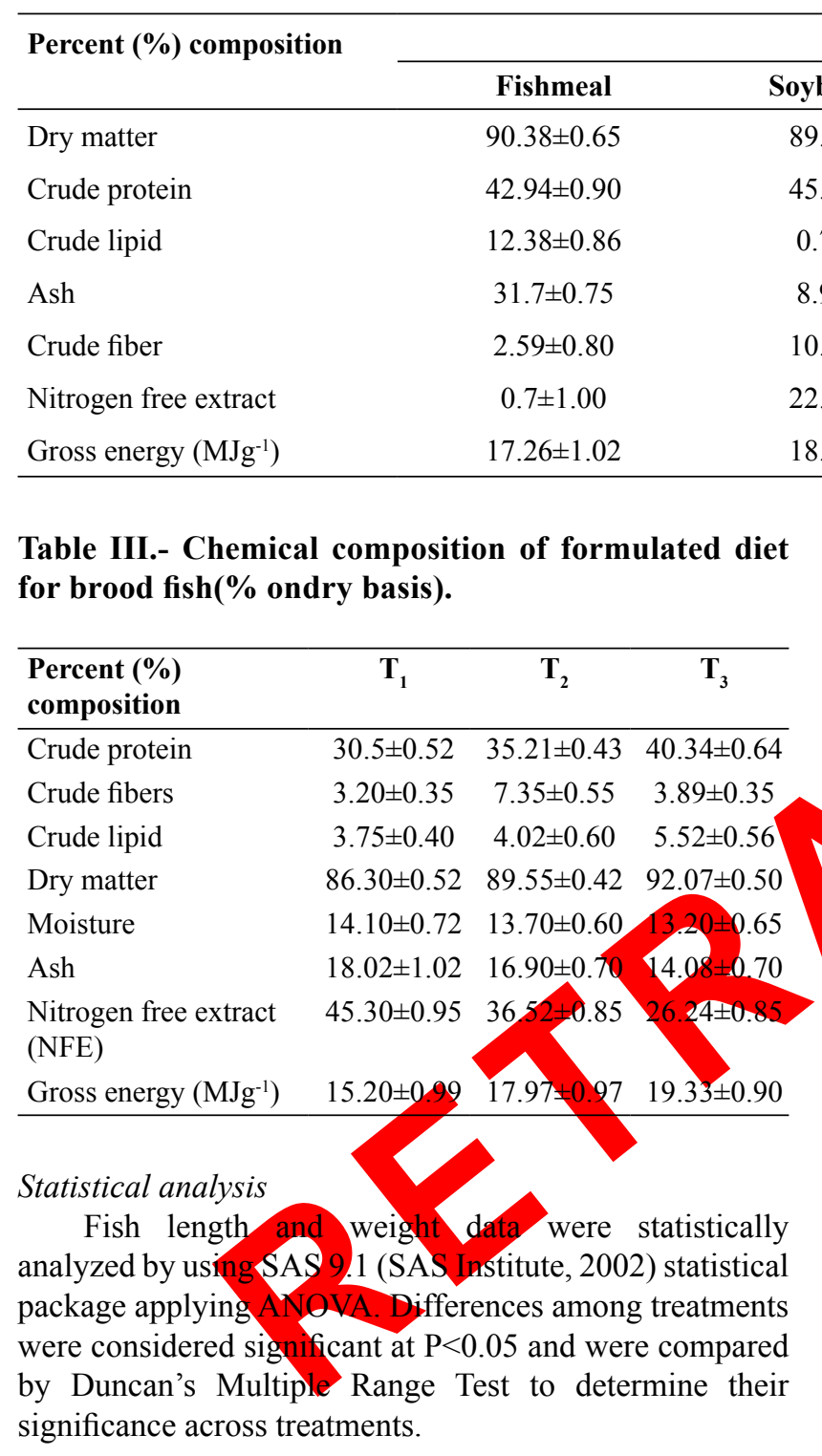

\section{RESULTS}

Chemical composition of feed ingredients and feeds

Nutritional composition of feed ingredients and formulated feeds is given in Tables II and III. Crude protein content of feed ingredients ranged from $13.9 \%$ to $45.9 \%$ with gross energy contents of 17.26 to $19.12 \mathrm{MJ} \mathrm{g}^{-1}$. Similarly, three isolipidic diets contained protein $30.5 \%$ $40.3 \%$ with dietary energy ranging from $15.2 \mathrm{MJg}^{-1}$ to 19.3 $\mathrm{MJg}^{-1}$.

\section{Body weight gain}

The initial average body weight of $C$. marulius brood

\section{Feed ingredients}

$\begin{array}{lcc}\text { Soybean meal } & \text { Maize gluten } & \text { Rice polish } \\ 89.41 \pm 0.99 & 91.09 \pm 1.00 & 90.02 \pm 0.85 \\ 45.92 \pm 1.02 & 39.54 \pm 1.05 & 13.9 \pm 0.90 \\ 0.72 \pm 1.03 & 1.03 \pm 1.02 & 10.9 \pm 0.95 \\ 8.96 \pm 1.23 & 7.27 \pm 1.05 & 15.69 \pm 0.80\end{array}$

$\begin{array}{lll}10.93 \pm 1.30 & 13.16 \pm 0.98 & 39.24 \pm 0.85\end{array}$

$22.88 \pm 1.40 \quad 30.09 \pm 0.85$

$18.99 \pm 1.20$ stock was $945.20 \pm 3.30 \mathrm{~g}, 952.83 \pm 2.88 \mathrm{~g}, 943.35 \pm 2.67 \mathrm{~g}$ and $947.88 \pm 2.55 \mathrm{~g}$, in control, $T_{1} T_{2}$ and $T_{3}$, respectively. The final average body weight of $C$. marulius was $1048.85 \pm 4.20 \mathrm{~g}, 1354.08 \pm 3.15 \mathrm{~g}, 1428.20 \pm 2.89 \mathrm{~g}$, and $1513.12 \pm 1.98 \mathrm{~g}$, and net weight gained was $103.65 \pm 0.12$ $\mathrm{g}, 401.25 \pm 0.14 \mathrm{~g}, 484.850 .12 \mathrm{~g}$ and $565.24 \pm 0.141 \mathrm{~g}$ in control, $\mathrm{T}_{2}, \mathrm{~T}_{2}$ and $\mathrm{T}_{3}$, respectively, which were significantly different $(\mathrm{P}<0.05)$ between fortnights and treatments (Tables IV and V). These results showed that $\mathrm{T}_{3}$ yielded the highest weight followed by $\mathrm{T}_{2}, \mathrm{~T}_{1}$, and control has the lowest. Differences were significant $(\mathrm{P}<0.05)$ in net weight gain and percent weight gain but values leveled off when we moved to specific growth rates.

\section{Proximate composition of eggs in $\mathrm{C}$. marulius}

Crude protein, crude lipid, moisture and total ash remained uniform among all dietary treatments $(\mathrm{P}>0.05)$ (Table VI). There was slight increase in crude protein and moisture contents with a rise in protein levels in feed from $30 \%$ to $40 \%$ CP. Crude lipids were $8.02 \pm 0.85 \%$ in control while $10.06 \pm 0.10 \%, 9.85 \pm 0.12 \%$ and $10.27 \pm 0.42 \%$ in $\mathrm{T}_{1}$, $\mathrm{T}_{2}$ and $\mathrm{T}_{3}$, respectively. Ash contents were found to be $0.80 \pm 0.03 \%, 0.62 \pm 0.02 \%, 0.35 \pm 0.04 \%$ and $0.24 \pm 0.01 \%$ in control, $\mathrm{T}_{1}, \mathrm{~T}_{2}$ and $\mathrm{T}_{3}$, respectively which decreased with increase in dietary protein levels. Crud fiber was not detected in any of the treatment and in control (Table VI).

\section{Proximate composition of whole body}

Crude protein (18.71\%) and crude lipid (2.68) were observed in $C$. marulius fed on $40 \%$ protein and were significantly different from control, $\mathrm{T}_{1}$ and $\mathrm{T}_{2}$. Moisture contents were significantly higher in control than treatments, while there were significant differences in ash contents between control and treatments. Carbohydrates were significantly different among control and in all treatments except control. Carbohydrates were significantly different in control and treatments (Table VII). 
Table IV.- Fortnightly average body weight gain(g) and total weight gain of Channa marulius brood stock in control and treatment ponds (June 2011-May 2012).

\begin{tabular}{|c|c|c|c|c|c|c|c|c|c|}
\hline \multirow{2}{*}{$\begin{array}{l}\text { No. of } \\
\text { Nettings }\end{array}$} & \multirow{2}{*}{ Fortnight } & \multicolumn{2}{|c|}{ Control } & \multicolumn{2}{|c|}{$\mathbf{T}_{1}$} & \multicolumn{2}{|c|}{$\mathbf{T}_{2}$} & \multicolumn{2}{|c|}{$\mathbf{T}_{3}$} \\
\hline & & $\begin{array}{l}\text { Total body } \\
\text { weight(g) }\end{array}$ & $\begin{array}{c}\text { Fish weight } \\
\text { gain(g) }\end{array}$ & $\begin{array}{l}\text { Total body } \\
\text { weight(g) }\end{array}$ & $\begin{array}{c}\text { Fish weight } \\
\text { gain(g) }\end{array}$ & $\begin{array}{l}\text { Total body } \\
\text { weight(g) }\end{array}$ & $\begin{array}{c}\text { Fish weight } \\
\text { gain(g) }\end{array}$ & $\begin{array}{l}\text { Total body } \\
\text { weight(g) }\end{array}$ & $\begin{array}{c}\text { Fish weight } \\
\text { gain(g) }\end{array}$ \\
\hline Initial & 01-06-11 & $945.20 \pm 3.30$ & - & $952.83 \pm 5.88$ & - & $943.35 \pm 5.39$ & - & $947.88 \pm 6.56$ & - \\
\hline 1 & $15-06-11$ & $949.30 \pm 5.15$ & $4.10 \pm 1.10$ & $972.08 \pm 6.10$ & $19.25 \pm 2.32$ & $965.40 \pm 7.19$ & $22.05 \pm 2.99$ & $973.18 \pm 6.29$ & $25.30 \pm 3.29$ \\
\hline 2 & $30-06-11$ & $953.35 \pm 4.12$ & $4.05 \pm 1.15$ & $992.88 \pm 8.17$ & $20.80 \pm 3.37$ & $988.45 \pm 5.39$ & $23.05 \pm 2.88$ & 1001 & $28.62 \pm 2.77$ \\
\hline 3 & $15-07-11$ & $959.05 \pm 5.12$ & $5.70 \pm 1.00$ & $1014.10 \pm 7.14$ & $21.23 \pm 3.45$ & $1013.13 \pm 6.23$ & $24.68 \pm 2.98$ & 7.34 & $30.35 \pm 3.68$ \\
\hline 4 & $30-07-11$ & $964.3 \pm 5.55$ & $5.25 \pm 1.25$ & $1037.37 \pm 5.29$ & $23.27 \pm 3.22$ & $1040.15 \pm 8.34$ & $27.03 \pm 3.99$ & .12 & $31.50 \pm 3.04$ \\
\hline 5 & $15-08-11$ & $970.4 \pm 3.45$ & $6.10 \pm 1.50$ & $1061.30 \pm 7.95$ & $23.93 \pm 3.56$ & $1069.15 \pm 8.37$ & $29.00 \pm$ & .24 & $32.05 \pm 3.49$ \\
\hline 6 & $30-08-11$ & $976.6 \pm 3.45$ & $6.20 \pm 2.00$ & $1084.73 \pm 8.96$ & $23.43 \pm 3.55$ & $1098.85 \pm 8.93$ & $29.70 \pm 3.77$ & & $32.30 \pm 4.12$ \\
\hline 7 & $15-09-11$ & $982.70 \pm 4.00$ & $6.10 \pm 1.85$ & $1106.02 \pm 8.24$ & $21.29 \pm 4.22$ & $1128.90 \pm 8.95$ & & & $31.83 \pm 4.23$ \\
\hline 8 & $30-09-11$ & $987.95 \pm 4.30$ & $5.25 \pm 1.50$ & $1124.27 \pm 7.34$ & $18.25 \pm 4.77$ & $1155.60 \pm 9.65$ & & & $27.67 \pm 3.52$ \\
\hline 9 & $15-10-11$ & $993.10 \pm 4.44$ & $5.15 \pm 1.25$ & $1139.49 \pm 9.81$ & $15.23 \pm 3.22$ & $1177.43 \pm$ & & & $24.06 \pm 5.22$ \\
\hline 10 & $30-10-11$ & $996.45 \pm 3.55$ & $3.35 \pm 1.00$ & $1152.42 \pm 9.93$ & $12.93 \pm 3.24$ & 1194. & & & $19.26 \pm 2.46$ \\
\hline 11 & $15-11-11$ & $999.45 \pm 5.50$ & $3.00 \pm 1.20$ & $1162.14 \pm 7.68$ & $9.73 \pm 2.89$ & & & & $17.33 \pm 2.97$ \\
\hline 12 & $30-11-11$ & $1002.4 \pm 3.40$ & $2.95 \pm 0.95$ & $1171.39 \pm 13.34$ & $9.25 \pm 4.12$ & & & 11.90 & $13.25 \pm 4.11$ \\
\hline 13 & $15-12-11$ & $1004.9 \pm 4.34$ & $2.50 \pm 1.00$ & $1180.62 \pm 11.33$ & $9.23 \pm 3.59$ & & & $24 \pm 8.96$ & $11.60 \pm 3.22$ \\
\hline 14 & $30-12-11$ & $1007.2 \pm 5.25$ & $2.30 \pm 1.10$ & $1189.54 \pm 15.44$ & $8.93 \pm 3.22$ & & & $1283.96 \pm 12.66$ & $10.72 \pm 4.11$ \\
\hline 15 & $15-01-12$ & $1009.3 \pm 3.45$ & $2.10 \pm 1.10$ & $1198.74 \pm 9.66$ & & & & $1294.96 \pm 14.61$ & $11.00 \pm 3.22$ \\
\hline 16 & $30-01-12$ & $1011.4 \pm 4.60$ & $2.10 \pm 1.35$ & $1209.04 \pm 12.95$ & & 1256. & 3.31 & $1308.28 \pm 12.33$ & $13.33 \pm 2.99$ \\
\hline 17 & $15-02-12$ & $1014.25 \pm 4.44$ & $2.85 \pm 1.60$ & $1220.39 \pm 13.45$ & & 1.26 & $14.85 \pm 3.24$ & $1324.63 \pm 9.88$ & $16.35 \pm 4.33$ \\
\hline 18 & $28-02-12$ & $1017.75 \pm 4.40$ & $3.50 \pm 1.80$ & $1233.80 \pm 14.55$ & & & $18.08 \pm 4.55$ & $1347.39 \pm 10.66$ & $22.76 \pm 4.43$ \\
\hline 19 & $15-03-12$ & $1021.85 \pm 4.30$ & $4.10 \pm 2.00$ & $1250.16 \pm 9.88$ & & $1310.57 \pm 12.16$ & $20.94 \pm 3.39$ & $1372.49 \pm 15.11$ & $25.10 \pm 5.11$ \\
\hline 20 & $30-03-12$ & $1026.65 \pm 4.45$ & $4.80 \pm 2.10$ & $1269.66 \pm 14.33$ & & $1333.19 \pm 12.46$ & $22.63 \pm 3.98$ & $1399.98 \pm 9.66$ & $27.49 \pm 5.23$ \\
\hline 21 & $15-04-12$ & $1031.7 \pm 3.55$ & $5.05 \pm 2.50$ & $1289.91 \pm 15.25$ & & $1356.79 \pm 14.15$ & $23.60 \pm 5.12$ & $1428.61 \pm 14.99$ & $28.63 \pm 6.14$ \\
\hline 22 & $30-04-12$ & $1037.2 \pm 3.45$ & $5.50 \pm 2.25$ & & \pm 5.33 & $1381.10 \pm 15.26$ & $24.31 \pm 6.27$ & $1458.01 \pm 15.11$ & $29.40 \pm 4.99$ \\
\hline 23 & $15-05-12$ & $1042.9 \pm 4.00$ & $5.70 \pm 2.45$ & & $21.83 \pm 4.55$ & $1405.90 \pm 13.98$ & $24.80 \pm 3.88$ & $1486.67 \pm 14.33$ & $28.67 \pm 6.11$ \\
\hline 24 & $30-05-12$ & $1048.85 \pm 4.20$ & $5.95 \pm 2.50$ & $1354.08 \pm 13.22$ & $20.85 \pm 5.55$ & $1428.20 \pm 15.44$ & $22.30 \pm 5.22$ & $1513.12 \pm 11.99$ & $26.45 \pm 5.99$ \\
\hline
\end{tabular}

Dissimilar superscripts horizontally show significant difference among each other at probability level of $\mathrm{P} \leq 0.05$.

Table V.- Weight gain, SGR, and \% survival of Channa marulius at the end of trial.

\begin{tabular}{|c|c|c|c|c|}
\hline Parameters & Control & $\mathbf{T}_{1}$ & $\mathbf{T}_{2}$ & $\mathbf{T}_{3}$ \\
\hline Initial weight & $945.20 \pm 3.30$ & $952.83 \pm 2.88$ & $943.35 \pm 2.67$ & $947.88 \pm 2.55$ \\
\hline Final weight (g) & $1048.85 \pm 4.20$ & $1354.08 \pm 3.16$ & $1428.20 \pm 2.89$ & $1513.12 \pm 1.99$ \\
\hline Net weight gain & $103.65 \pm 0.12^{\mathrm{d}}$ & $401.25 \pm 0.14^{\mathrm{c}}$ & $484.85 \pm 0.13^{b}$ & $565.24 \pm 0.14^{\mathrm{a}}$ \\
\hline Percent weight gain $(\%)$ & $10.96 \pm 1.10^{\mathrm{d}}$ & $42.11 \pm 1.67^{\mathrm{c}}$ & $51.39 \pm 1.55^{\mathrm{b}}$ & $59.63 \pm 1.47^{\mathrm{a}}$ \\
\hline Specific growth rate (\% wt. gain/day) & $0.03 \pm 0.003^{\mathrm{b}}$ & $0.04 \pm 0.01^{\mathrm{a}}$ & $0.05 \pm 0.005^{\mathrm{a}}$ & $0.06 \pm 0.002^{\mathrm{a}}$ \\
\hline Survival $(\%)$ & $70 \pm 4.20$ & $100 \pm 2.88$ & $100 \pm 2.76$ & $100 \pm 2.45$ \\
\hline
\end{tabular}

Dissimilar superscripts horizontally show significant difference among each other at probability level of $\mathrm{P} \leq 0.05$.

Table VI.- Chemical composition of the eggs of brooder Channa marulius supplied with diets having different protein levels.

\begin{tabular}{lcccc}
\hline Parameters & Control & $\mathbf{T}_{1}$ & $\mathbf{T}_{2}$ & $\mathbf{T}_{3}$ \\
\hline Egg weight (g) & $10.20 \pm 0.90^{\mathrm{d}}$ & $15.61 \pm 1.29^{\mathrm{c}}$ & $18.02 \pm 0.53^{\mathrm{b}}$ & $19.81 \pm 1.31^{\mathrm{a}}$ \\
Crude protein (\%) & $63.20 \pm 1.03^{\mathrm{c}}$ & $69.49 \pm 0.93^{\mathrm{b}}$ & $71.25 \pm 1.38^{\mathrm{a}}$ & $72.56 \pm 1.75^{\mathrm{a}}$ \\
Crude lipids (\%) & $8.02 \pm 0.85^{\mathrm{b}}$ & $10.06 \pm 0.10^{\mathrm{a}}$ & $9.85 \pm 0.12^{\mathrm{a}}$ & $10.27 \pm 0.42^{\mathrm{a}}$ \\
Moisture (\%) & $5.85 \pm 0.03^{\mathrm{b}}$ & $6.02 \pm 0.02^{\mathrm{b}}$ & $6.08 \pm 0.02^{\mathrm{b}}$ & $6.50 \pm 0.21^{\mathrm{a}}$ \\
Total ash (\%) & $0.80 \pm 0.03^{\mathrm{a}}$ & $0.62 \pm 0.02^{\mathrm{b}}$ & $0.35 \pm 0.04^{\mathrm{c}}$ & $0.24 \pm 0.01^{\mathrm{d}}$ \\
Crude fiber (\%) & ND & ND & ND & ND $^{\mathrm{a}}$ \\
\hline
\end{tabular}

ND, not detectable. 
Table VII.- Body composition of whole Channa marulius brood stock fed on different dietary protein levels.

\begin{tabular}{lcccc}
\hline Parameters & Control & $\mathbf{T}_{1}$ & $\mathbf{T}_{2}$ & $\mathbf{T}_{3}$ \\
\hline Crude protein (\%) & $16.50 \pm 0.12^{\mathrm{bc}}$ & $17.80 \pm 0.02^{\mathrm{b}}$ & $17.92 \pm 0.02^{\mathrm{b}}$ & $18.71 \pm 0.20^{\mathrm{a}}$ \\
Crude lipids (\%) & $1.98 \pm 0.01^{\mathrm{b}}$ & $2.03 \pm 0.01^{\mathrm{b}}$ & $2.56 \pm 0.01^{\mathrm{b}}$ & $2.68 \pm 0.07^{\mathrm{a}}$ \\
Moisture (\%) & $75.10 \pm 0.17^{\mathrm{a}}$ & $74.38 \pm 0.18^{\mathrm{a}}$ & $73.86 \pm 0.05^{\mathrm{b}}$ & $73.69 \pm 0.04^{\mathrm{b}}$ \\
Total ash (\%) & $2.10 \pm 0.10^{\mathrm{b}}$ & $2.11 \pm 0.07^{\mathrm{a}}$ & $2.27 \pm 0.17^{\mathrm{a}}$ & $2.25 \pm 0.13^{\mathrm{a}}$ \\
Carbohydrates (\%) & $4.25 \pm 0.03^{\mathrm{a}}$ & $3.86 \pm 0.05^{\mathrm{b}}$ & $3.38 \pm 0.13^{\mathrm{c}}$ & $2.46 \pm 0.24^{\mathrm{d}}$ \\
Crude fiber (\%) & ND & ND & ND & ND \\
\hline
\end{tabular}

ND, not detectable.

Table VIII.- Physico-chemical parameters of the experimental pond water.

\begin{tabular}{|c|c|c|c|}
\hline Parameters & Control & $T_{1}$ & $T_{3}$ \\
\hline Water temperature $\left({ }^{\circ} \mathrm{C}\right)$ & $29.50 \pm 1.30$ & $29.32 \pm 1.30$ & $30.20 \pm 1.72$ \\
\hline Dissolved oxygen (DO) mg/l & $5.80 \pm 0.95$ & $5.40 \pm 0.95$ & $5.20 \pm 1.12$ \\
\hline $\mathrm{pH}$ & $7.40 \pm 0.14$ & $7.50 \pm 0.14$ & $7.20 \pm 0.21$ \\
\hline Salinity $(\mathrm{mg} / \mathrm{l})$ & $0.82 \pm 0.08$ & $0.83 \pm 0.08$ & $0.82 \pm 0.05$ \\
\hline Total dissolved solid (TDS) & $1622.05 \pm 75.30$ & $1624.05 \pm 75$ & $1540.10 \pm 65.71$ \\
\hline Electrical conductivity (EC) & $2.15 \pm 0.22$ & $2.12 \pm 0.2$ & $2.10 \pm 0.12$ \\
\hline
\end{tabular}

Water quality and Loshmann, 2008) documented similar findings which

Water quality parameters of control and treated ponds are given in Table VIII. The water temperature was maintained at $30.2 \pm 0.2^{\circ} \mathrm{C}$. Dissolved oxygen $\mathrm{w}$ $5.5 \pm 0.3 \mathrm{mg} / \mathrm{l}$. Ph was kept constant at 7.5 and salinity was $0.8 \pm 0.03 \%$. Total dissolved solids (TDS) and electrical conductivity were $1620 \pm 1.5 \mathrm{mg} / 1$ and $2.2 \pm 0.1 \mathrm{mmb} / \mathrm{cm}$, respectively.

further support our observations on C. marulius. Our studies also suggest that $30 \%$ protein level is not enough for optimal growth and performance of other bodily functions in $C$. marulius. Energy is another important nutritional parameter, which retards growth if provided in insufficient amounts (NRC, 1993). Chow and Watanabe (1988) recommended that adult fishes need more energy for maintenance of their body functions, development of gonads, fecundity and better performance of hatchlings.

In this study, eggs in $T_{3}$ displayed maximum

In the present study, the dietary protein level of $40 \%$ with $19.33 \mathrm{MJg}^{-1}$ energy was adequate to optimize growth, feed conversion and egg quality alongwith body composition of $C$. manulius broodstock. This level is in agreement with the reported values for variety of fish species (Harper, 1988; El-Sayed et al., 2003; Chong et al., 2004). They stated that better protein levels in broodstock feeds correlates with level of gonad development and quality of spawn. Moreover, El-Sayed and Kawanna (2008) described that Tilapia nilotica brood stock showed significant growth increments with rise in energy and dietary protein levels. These differences were more prominent when protein level was increased from $30 \%$ to $40 \%$ and the energy level from $15.20 \pm 0.99 \mathrm{MJ} / \mathrm{Kg}$ to $19.33 \pm 0.90 \mathrm{MJ} / \mathrm{Kg}$ at each level. Some other researchers who performed similar type of work on different fish species like Dicentrarchus labrex (Cerda et al., 1994) Oreochromis niloticus (El-Sayed et al., 2003) Labeo rohita (Afzal et al., 2005) and Ictalurus punctatus (Sink percentage of crude protein, crude lipid, moisture and total ash contents. These values corroborates with those of Sotolu and Kigbu (2011) who observed increased body protein and much better gonad development in catfish up to $40 \%$ protein inclusion in formulated feeds. Evidence to support this is available in studies of Gunasekara et al. (1996), Muchlisin et al. (2006) and Sotolu and Kigbu (2011). They suggested that $40 \%$ protein level in formulated feeds is advisable for proper growth and reproductive performance of this and other catfishes. The chemical analysis of fish meat indicated that protein, lipid, ash, carbohydrates and moisture contents were higher in $\mathrm{T}_{3}$ as compared to $\mathrm{T}_{2}, \mathrm{~T}_{1}$ and Control though statistically these differences were insignificant $(\mathrm{P}>0.05)$. The values of protein contents, moisture and lipid were higher in $\mathrm{T}_{3}$ than those of other groups, which may be due to higher percentage of protein inclusion levels. Viola et al. (1982) while working on similar type of studies reported that nutrient levels present in feed are depicted 
in body composition. High concentration of protein and lipid results in significant increase in weight of the carps. In this study, it was observed that if lipid contents are found in low concentration, the protein contents will be lower and the growth will be lower as well. These findings corroborate with the observation of Jirasek et al. (1984). They mentioned that high feeding rate or daily ration level increases fish weight. In addition, it enhances the feed conversion as protein and lipid contents are increased in carps. Zeitler et al. (1984) with similar findings described a significant relationship between protein and fat contents. In the current research, the highest protein level was $18.22 \pm 0.22 \%$ in $\mathrm{T}_{3}, 17.92 \pm 0.02 \%$ in $\mathrm{T}_{2}$ and $17.80 \pm 0.02 \%$ in $\mathrm{T}_{1}$ while the lowest was $16.50 \pm 0.12 \%$ in Control. Moisture in control pond $(30.0 \% \mathrm{CP})$ were high in which lower growth was found as compared with all other treatments. This might have been due to low protein deposition and accumulation of surplus water. Our findings corroborate with those of Riaz (2008) who reported that higher moisture contents in fish body related to low protein levels in the diet, experienced during predator-prey relationship studies in which $C$. marulius was deprived of sufficient live feed (tilapia). The present findings are also very close to those of Love (1980) who examined that fish consumed the fat from the liver during starvation and then started to draw muscle protein with depletion of available energy sources. Water contents replaced the exhausted protein reserves during this scenario

\section{CONCLUSION}

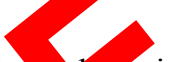

The present study showed maximum feed utilization, growth, and the best egg quality and body composition in $40 \%$ CP containing feed group, followed by $35 \% \mathrm{CP}, 30 \%$ $\mathrm{CP}$ and control. These studies suggest that $40 \%$ protein diet is required for better growth, health and egg development in C. marulius.

\section{Statement of conflict of interest}

Authors have declared no conflict of interest.

\section{REFERENCES}

Afzal, K.M., Jafri, A.K. and Chadha, N.K., 2005. Effects of varying dietary protein levels on growth, reproductive performance, body and egg composition of rohu, Labeo rohita (Hamilton). Aquacult. Nutr., 11: 11-17. https://doi.org/10.1111/ j.1365-2095.2004.00318.x

AOAC, 2005. Official methods of analysis, $18^{\text {th }}$ edition. Association of Official Analytical Chemist, pp. 690. Berglund, I., 1995. Effects of spring temperature and feeding regime on sexual maturation in Atlantic salmon (Salmo salar L.) male parr. In: Proceedings of the Fifth International Symposium on the Reproductive Physiology of Fish (eds. F.W. Goetz and P. Thomas). Fish Symposium 95, Austin, TX, USA, pp. 170-172.

Blom, J.H. and Dabrowski K., 1995. Reproductive success of female rainbow trout (Oncorhynchus mykiss) in response to graded dietary ascorbyl monophosphate levels. Biol. Reprod., 52: 10731080. https://doi.org/10.1095/biolreprod52.5.1073

Brooks, S., Tyler, C.R. and Sumpter, J.P., 1997. Egg quality in fish. what makes a good egg? Rev. Fish Biol., 7: 387-416. https://doi. org/10.1023/A.10184001306

Cerda, J., Carrillo, M., Zanuy, S., Ramos, J. and Dela Higuera, M, 1994. Influence of nutritional composition of diet on sea bass, Dicentrar chuslabrax L., reproductive performance and egg and laval quality. Aquaculture, 128: 345-361. https;/tloi.org/10.1016/0044-8486(94)90322-0

Cho, C.Y. and Watanabe, T., 1988. Laboratory work chemical evaluation of dietary nutrition. In: Fish nutrition and mariculture JICA textbook, General Aquaculture Course (ed. T. Watanabe). Kanagawa International Fisheries Training Center, Tokyo, pp. 79-92.

Chong, A.S.C., Ishak, S.D., Osman, Z. and Hashim, R., 2004. Effect of dietary protein level on the reproductive performance of female swordtails Xipho phorushelleri (Poecciliidae): Aquaculture, 234: $\quad 381-392$. https://doi.org/10.1016/j. aquaculture.2003.12.003

Choubert, G., Blanc, J.M. and Poisson, H., 1998. Effects of dietary keto-carotenoids (Canthaxanthin and astaxanthin) on the reproductive performance of female rainbow trout Oncorhynchus mykiss (Walbaum). Aquacult. Nutr., 4: 249-254. https:// doi.org/10.1046/j.1365-2095.1998.00078.x

Choubert, G. and Blanc, J.M., 1993. Muscle pigmentation changes during and after spawning in male and female rainbow trout, Oncorhynchus mykiss, fed dietary carotenoids. Aquat. Living Resour., 6: 163-168. https://doi.org/10.1051/ alr:1993016

Christiansen, R. and Torrissen, O.J., 1997. Effects of dietary astaxanthin supplementation on fertilization and egg survival in Atlantic salmon (Salmosalar L.). Aquaculture, 153: 51-62. https://doi.org/10.1016/ S0044-8486(97)00016-1

Cumaratunga, P.R.T. and Mallika, K.L.G.P., 1991. Effects of different levels of dietary protein and 
a legume Vigna catiang on gonadal development in Oreochromis niloticus (L.). In: Fish nutrition research in Asia (ed. S.S. de Silva). Proceedings of the Fourth Asian Fish Nutrition Workshop, Asian Fisheries Society Special Publication 5. Asian Fish. Soc, Manila, Philippines, pp. 125-133

de silva, S.S. and Anderson, T.A., 1995. Fish nutrition in aquaculture. Chapman \& Hall Aquaculture Series 1, Chapman \& Hall, London, U.K., pp. 219.

El-Sayed, A.F.M. and Kawanna, M., 2008. Effects of dietary protein and energy levels on spawning performance of Nile tilapia (Oreochromis niloticus) brood stock in a recycling system. Aquaculture, 280: $\quad 179-184$. https://doi.org/10.1016/j. aquaculture.2008.04.030

El-Sayed, A.F.M., Mansour, C.R. and Ezzat, A.A., 2003. Effects of dietary protein levels on spawning performance of Nile tilapia (Oreochromis niloticus) broodstock reared at different water salinities. Aquaculture, 220: 619-632. https://doi. org/10.1016/S0044-8486(02)00221-1

Eskelinen, P., 1989. Effects of different diets on egg production and egg quality of Atlantic salmon (Salmo salar L.). Aquaculture, 79: 275-281. https:// doi.org/10.1016/0044-8486(89)90468-7

Fernandez-Palacios, H., Izquierdo, MS., Robaina, L., Valencia, A., Salhi, M. and Vergara, J., 1995. Effect of n-3 HUFA level in broodstock diets on egg quality of gilthead seabream (Sparus aurata L.). Aquaculture, 132. 325-337. https://doi. org/10.1016/0044-8486(94)00345-O

Fernandez-Palacios, H., Izquierdo,M.S., Robaina, L., Valencia, A. Salhi, M. and Montero, D., 1997. The effect of dietary protein and lipid from squid and fish meals on egg quality of broodstock for gilthead seabream (Sparus aurata). Aquaculture, 148: 233-246. https://doi.org/10.1016/S00448486(96)01312-9

Gunasekera, R.M., Shim, K.F. and Lam, T.J., 1995. Effect of dietary protein level on puberty, oocyte growth and egg chemical composition in the tilapia, Oreochromis niloticus (L.). Aquaculture, 13: $169-183 . \quad$ https://doi.org/10.1016/00448486(95)00028-Z

Gunasekera, R.M., Shim, K.F. and Lam, T.J., 1996a. Effect of dietary protein level on spawning performance and amino acid composition of eggs of Nile tilapia, Oreochromis niloticus. Aquaculture, 146: 121-134. https://doi.org/10.1016/S00448486(96)01365-8

Gunasekera, R.M., Shim, K.F. and Lam, T.J., 1996 b. Influence of protein content of broodstock diets on larval quality and performance in Nile tilapia, Oreochromis niloticus (L.). Aquaculture, 146: 245-259. https://doi.org/10.1016/S00448486(96)01380-4

Gunasekera, R.M., Shim, K.F. and Lam, T.J., 1997. Influence of dietary protein content on the distribution of amino acids in oocytes, serum and muscle of Nile tilapia, Oreochromis niloticus (L.). Aquaculture, 152: 205-221. https://doi.org/10.1016/ S0044-8486(96)01526-8

Hafeez-ur-Rehman, M., Abbas, F., Ashraf, M., Narejo, N.T., Iqbal, K.J. and Andleeb, S. 2017. Effect of different dietary protein levels on egg development and its response to inducing agents during induced spawning of Channa marulius Pakistan J. Zool, 49: $337-343$

Hardy, R.W., Shearer, K.D. and King, I.B., 1984. Proximate and elemental composition of developing eggs and maternal soma of pen-reared coho salmon (Oncorhynchus kisutch) fed production and trace element fortified diets. Aquaculture, 43: 147-165. https://oi.org/10.1016/0044-8486(84)90018-8

Harper, J.E., 1988. Fish nutrition. Academic Press Inc., London, pp. 798.

Hanifa, M.A.K. and Sridhar, S., 2002. Induced spawning of spotted murrel, Channa punctatus and catfish Heteropneustes fossilis using human chorionic gonadotropin and synthetic hormone (ovaprim). Vet. Arch., 72: 51-56.

Hopkins, K.D., 1992. Reporting fish growth: A review of the basics. J. World Aquac. Soc., 23:173-179.

Izquierdo, M.S., Fern'andez-palacios, H. and Tacon, A.G.J., 2001. Effect of brood stock nutrition on reproductive performance of fish. Aquaculture, 197: 25-42. https://doi.org/10.1016/S00448486(01)00581-6

Javed, M. and Sial, M.B., 1991. Fish pond fertilization. III. Effect of layer manure fertilization on the growth performance of fish viz., Catla catla, Labeo rohita and Cirrhinus mrigala. Pak. J. Agric. Sci., 28: $115-120$.

Jirasek, J., Spurny, P. and Janesov, L., 1984. Effect of different dietary feeding frequency on body growth, feed conversion and nutrient retension in carp fry. Zivvcisna Skola Vyroba, 29: 983-989.

Kothari, C.R., 2004. Research methodology; methods and techniques (second Revised Edition). New Age International Publishers, India, pp. 401.

Love, R.M., 1980. The chemical biology of fishes $\left(3^{\text {rd }}\right.$ ed.). Academic Press, Inc., London, pp. 547.

Manissery, J.K., Krishnamurthy, D., Gangadhara, B. and Nandeesha, M.C., 2001. Effect of varied levels 
of dietary protein on the breeding performance of common carp Cyprinus carpio. Asian Fish. Sci., 14: 317-322.

Marimuthu, K.M. and Hanifa, A., 2007. Embryonic and larval development of the striped snakehead Channa striatus. Taiwania, 52: 84-92.

Metcoff, J., 1986. Intracellular amino acid levels as predictors of protein synthesis. J. Am. College Nutr., 5: 107-120. https://doi.org/10.1080/0731572 4.1986.10720118

Mourente, G. and Odriozola, J.M., 1990. Effect of brood stock diets on lipid classes and their fatty acid composition in eggs of gilthead sea bream (Sparus aurata L.). Fish Physiol. Biochem., 8: 93101. https://doi.org/10.1007/BF00004437

Muchlisin, Z.A., Hashim, R. and Chong, A.S.C., 2006. Influence of dietary protein levels on growth and egg quality in broodstock female Bagrid catfish (Mystus nemurus Cuv. \& Val.): Aquacult. Res., 37: 416-418. https://doi.org/10.1111/j.1365-2109.2005.01382.x

NRC, 1993. National Research Council, Sub-commitee on Warm water fish nutrition. Nutrient requirements of fish. National Academy of Science, Washington DC, pp. 114.

Pereira, J.O.B., Reis-Henriques, M.A., Sanchez, J.L. and Costa, J.M., 1998. Effect of protein source on the reproductive performance of female rainbow trout, Oncorhynchus mykiss (Wałbaum). Aquacult. Res., 29: 751-760. https://do1.org/10.1046/j,3652109.1998.29100751

Riaz, M.A., 2008. Studies on the feasibility of raising Channa marulius with tilapia (Oreochromis mossambicus) by using different predator-prey stocking ratios in fertilized ponds. PhD thesis, University of Agriculture, Faisalabad.

Santiago, C.B. and Reyes, O.S., 1993. Effects of dietary lipid source on reproductive performance and tissue lipid levels of Nile tilapia Oreochromis niloticus (Linnaeus) broodstock. J. appl. Ichthyol., 9: 33-40. https://doi.org/10.1111/j.1439-0426.1993. tb00385.x

Siddiqui, A.Q., Al-Hafedh, Y.S. and Ali, S.A., 1998.
Effect of dietary protein level on the reproductive performance of Nile tilapia, Oreochromis niloticus (L.). Aquacult. Res., 29: 349-358. https://doi. org/10.1111/j.1365-2109.1998.tb01140.x

Sink, T.D. and Lochmann, R.T., 2008. Effects of dietary lipid source and concentration on channel catfish (Ictalurus punctatus) egg biochemical composition, egg and fry production, and egg and fry quality. Aquaculture, 283: 68-76. https://doi.org/10.1016/j. aquaculture.2008.07.024

Sotolu, A.O. and Kigbu, A.A., 2011. Growth and gonad quality of Clarias gariepinus (Burchell, 1822) brood stock fed varying dietary protein levels. Public. Nasarawa State Univ. Keffi, 7: 61-67. www. patnsukjournal.net currentissu

Viola, S., Mokady, S., Rapport, U. and Arieli, Y., 1982. Partial and complete replacement of fish meal by soybean meal in feed for intensive culture of carp. Aquaculture, 26: 223-236. https://doi. org/10.1016/0044-8486(82)90158-2

ashburn, B.S., Frye, D.J., Hung, S.S.O., Doroshov, S.I. and Conte, F.S., 1990. Dietary effects tissue composition, oogenesis and the reproductive performance of female rainbow trout (Oncorhynchus mykiss). Aquaculture, 90: 179-195. https://doi.org/10.1016/0044-8486(90)90340-S

Watanabe, T. and Kiron, V., 1995. Red sea bream (Pagrus major). In: Broodstock management and egg and larval quality (eds. N.R. Bromage and R.J. Roberts). Blackwell Science, Oxford, pp. 398-413.

Zakeri, M., Jasem, G.M., Preeta, K., Ahmad, S., Vahid, Y. and Mahsa, H., 2009. Effects of protein and lipid concentrations in broodstock diets on growth, spawning performance and egg quality of yellowfin sea bream (Acanthopagrus latus). Aquaculture, 295: 99-105. https://doi.org/10.1016/j. aquaculture.2009.06.026

Zeitler, M.H., Kirchgessner, M. and Schwarz, F.J., 1984. Effects of different protein and energy supplies on carcass composition of carp (Cyprinus carpio L.). Aquaculture, 36: 37-48. https://doi. org/10.1016/0044-8486(84)90052-8 